\title{
REFLECTION ON PERSONAL DEVELOPMENT, FACTS AND RULES TO BE APPLIED IN THE MANAGEMENT OF COMPANIES
}

\section{Cristina Gabriela VASCIUC ${ }^{1 *}$}

\begin{abstract}
Received: April 2020 | Accepted: June 2020 | Published: August 2020
Please cite this paper as: Vasciuc, C.G. (2020) Reflection on Personal Development, Facts and Rules To Be Applied in The Management of Companies, Holistica Journal of Business and Public Administration, vol. 11, iss. 2, pp. 140-150
\end{abstract}

\begin{abstract}
The employees' personal development is essential in the current management. The companies that perform have several competent managers and they manage to evolve and retain the talents, rewarding the services. By implementing a careful personal development strategy, they have a real competitive advantage, becoming a priority for companies. This helps their employees to establish a better relationship with themselves and others, a sign of personal and professional evolution. The personal development ensures the employees' well-being, so that they increase their productivity. Personal development practices must integrate each branch of a company, from production to management, personal development now being part of managers' tools, its purpose being to help managers get to know each other better and to control their interactions with others, pushing employees to respect the expected behavior of the organization. Thus, personal development becomes indispensable to the nowadays' management, being advantageous for the company, because, not only does it improve communication within the company, but it also has an impact on its performance and productivity.
\end{abstract}

Keywords: personal development, management, managers, competitive advantage Jel code: M14, M51, M52, M54, L5

\section{Introduction}

The purpose of any business is its development. Thus, besides the technical and logistical improvement, the emphasis must be placed on the personal development of the employees, because there is a close connection between the well-being of the employees and the performance of the company. Human resource management uses the personal development approach to increase employees' skills and capabilities, which increases productivity and encourages creativity. Through a personal growth program, the company can increase its level of competitiveness and performance. In fact, the training initiatives for personal development help to strengthen the motivations of the employees who will

\footnotetext{
${ }^{1}$ Valahia University Targoviste, Romania, crisabebe2005@yahoo.com

* Corresponding author
} 
feel more comfortable in their work place, due to the methods they have learned. Therefore, the collective performance will be based on a good cohesion of the groups.

Currently, business leaders strongly encourage the practice of these methods, because the need to strengthen professional ties and efficient collaboration between different hierarchies of the company, no longer doubt. With knowledge, time management skills, organizational methodologies and management techniques, managers can use them as valuable assets for the company's productivity and performance. Personal development helps to enhance creativity and harmony in personal, social and professional life by encouraging the individual to overcome their difficulties (managing their stress, time, improving communication, relationships with others, achieving their goals). The benefits of personal development are manifold. At work is considered an indispensable tool for competition, in everyday life it is a tool to cope with life's challenges (you can learn how to combat fears and escape from comfort zone). Therefore, it is essential to progress to develop various skills, to create a positive, optimistic, learning-oriented attitude, so people are capable of much more when they are perfected.

\section{Review of the specialized literature}

Many experts claim that HRD plays an essential role in the development of individuals and organizations and, consequently, in maintaining an economically competent and productive workforce. HRD is all about people's development, including promotion policies, professional development and counselling, staff evaluation, competency definition, organizational planning and ethics policies. At the same time, it is important for young people and unemployed ones to have solid, professional, knowledge (Amri, 2007).

\subsection{Socio-historical perspectives of personal development}

The field of continuing education has evolved considerably over the last four decades, both at the federal and provincial levels. Since the 1960s, I have become aware of the lack of training in most of the workforce. Technical and vocational training is also important, especially for young people and the unemployed. Thus, the imperatives of competitiveness are to develop a culture of personal development in the workplace; to establish a true partnership between government, employers and labor unions; to simplify and streamline the management of work programs; to obtain the contribution of educational networks.

The concepts of training, development, education and apprenticeship in the workforce are often confused. We find the formation of the employed and unemployed active population, employer-sponsored training, in-house training, on-the-job training, on-thejob training, on-the-job training, on-the-job training, on-the-job training, on-the-job training, business coaching, training in the workplace, training of the labor force, training in the industry, industrial training, training of the personnel headed by the companies and finally the training in the workplace. 
HRM bibliography qualifies various forms of training, regardless of internal or external training, as training for young recruits or adult training or formal or informal training.

Adult education is defined as: the set of learning processes, formal or otherwise, through which individuals considered adults in the society of which they are part develop their skills, enrich their knowledge and improve their skills. According to the Ministry of Education, although education and personal development are similar, both refer to a learning process designed to develop skills, improve knowledge, improve skills or reorient them according to the needs of the individual and society. However. it is possible to distinguish these concepts by giving education a more academic and continuous dimension, a socio-economic connotation.

\subsection{Definitions of personal development}

It is an activity or set of activities decided or granted by the employer alone or in collaboration with its staff or representatives, designed to develop different types of skills or attitudes related to the employment of employees, of a company or an organization (Bartlett, 2001). The objectives are to enable new employees to do their work more efficiently, to have greater control over their activity and greater control over changes and, as the case may be, prepared to assume other duties or responsibilities within the same enterprise, in the same industry or elsewhere, as a result of technical or organizational or employee's initiative (Di Raddo, 2002; Tremblay, Guay \& Simard, 2000).

Personal development refers to all formal and other learning by which individuals develop their skills, acquire and improve their professional knowledge and qualifications according to their own needs and those of the company (Berube, 2000; Campeau, 2002). It is part of a lifelong learning perspective, as well as basic education, which should prepare students to acquire the basics and methods that will allow them to continue learning throughout their lives and giving the necessary impulse. Similarly, the Ministry of Education considers that personal development must acquire the qualifications that allow the integration or reintegration of the labor market (preparation for employment and integration) and facilitates the adaptation of workers to the change of the labor market (retention, stabilization of employment and job creation).

In the specialized literature, continuing education refers to training according to the real needs of the organization, which should focus on developing skills and knowledge to help the employee to improve their performance and have the opportunity to grow within the company (Garavan, 1997; Tremblay, 2001). Personal development is considered the engine of business growth, because people who acquire new skills in their trades can better respond to the future needs of the company; some researchers say that continuing education can be planned by the employer (Garavan et.al, 2020)

Training is referred as "a set of development activities that enable employees to acquire the skills needed to learn the current job or to meet the future needs of the organization" (Laberge, Wils \& Labelle, 1995). According to Dubar (2010) continuing education is directly 
rooted in realities. It defines it as: "training activities planned in advance and financed in whole or in part by the employer".

The UNESCO definition of the adult education sector provides us with a descriptive definition of the continuous education of corporate personnel and other organizations, as follows: the whole of the organized educational processes. Whatever the content, level and method, formal or non-formal, they extend or replace initial education offered in schools and universities and in a form of vocational learning, through which people have considered through the society of which they are part, develop skills, enrich their knowledge, improve technical or professional qualifications.

Continuous training can be considered as a form of recognition of the employee's efforts, it is a form of satisfaction which will strengthen the staff's commitment to the values of his activity (Bélanger, 2004). The employee considers that the organization is concerned about the workforce (Lapalme, Simard, De la Sablonnière, 2002), he perceives as a promise of trust and the commitment of the company.

As part of this study, we consider personal development as a set of internal or external development activities proposed to employees to update or acquire new skills necessary to fulfil their employment or in response to the future needs of the company.

\subsection{The influence variables of personal development}

The success factors of training within a company are possible if the training activities:

- contributes to a global strategy

- I get people's support

- meet well identified and well-oriented needs

- allow adequate cumulative learning

- make it possible to build verifiable and recognized skills

- are followed by means appropriate to the needs and availability of the persons concerned.

\subsection{The values and challenges of organizations}

It seems that leaders' values in training are crucial in deciding to implement personal development practices.

Thus, it seems that organizations must assess the benefits and disadvantages before deciding to invest in training activities. Companies calculate the extent to which training contributes to the achievement of organizational goals by transmitting key values, preparing for changes or developing versatility. The main disadvantages mainly concern the costs too much the benefits obtained or the lack of consensus regarding the importance of training (Tremblay, 2002).

\subsection{Continuing education programs}

The training program should start with a needs-analysis: 
- In the organization: This phase consists in delimiting the service (s) that will have to benefit in the organization and evaluating its usefulness.

Job analysis helps to identify what should be included in the training by describing the job that lists the essential tasks, as well as the knowledge, skills and abilities needed to improve efficiency.

- According to the person

The person's analysis identifies the employees who should be trained.

This analysis can be done through an assessment of skills or tests.

Also after following these steps of needs analysis, managers should be able to list the training courses that follow a training strategy to use and, finally, to prepare the training program (s): 1. Task adaptation programs, 2. Structured and qualified training programs,

3. On-the-job training programs, 4. Qualified training programs, 5. Transferable training programs.

\subsection{Indicators of continuing education}

Continuing education, as defined by Dubar (2004), corresponds to a set of training activities, which include:

- Internships within the company, external internships in organizations or other units

- Training in a work situation

- Participations for training purposes, seminars, conferences; or other meetings (quality circles, etc.)

- Job rotations to learn a new job

- self-training (distance learning, multimedia, etc.).

\section{Research methodology}

The paper uses a qualitative research method to discover possible explanations between the different variants presented by personal development. This introductory approach aims to explain the problem in its context and dynamics (Navarro-Flores, 2009). Qualitative data are presented in words based on observation, documents or interviews (Miles \& Hubermon, 1994). Thus, exploratory research was made, so it will require more follow-up studies. In order to carry out this work, it was necessary to use the information available in the specialized literature, as well as the semi-structured interview with Romanian multinational employees, consisting of a flexible verbal interaction, in the form of a conversation, being easier to use and allowing direct access to the experience of the people. The semi-structured interview was built around six major themes: guidelines and guiding principles of human development, skills development, transfer of experience, attracting and retaining employees, roles and responsibilities of each in human development, and, training methods and practices used. 
At the same time, secondary research methods were also used, whose informational resources were: "Nicolae lorga" from Ploiesti, Romanian and international business books and publications, newspapers and magazines.

\section{Findings}

\subsection{Improvement and development of skills}

The development of training for employment has become an important element in promoting the degree of employment of the people and in meeting the market requirements for efficiency and flexibility. Training can be defined as all activities designed to make employees capable of competently performing their tasks. It involves a transfer or even an exchange of knowledge between management and the workforce. Both the employer and the worker are now responsible for improving the skills within the company (Tremblay, 2002; Sassler \& Miller, 2017).

The training should go beyond the technique and include the know-how gained through experience and the label regarding the attitudes and behaviors of work that are other components of the skill that must be acquired. One of the responsibilities of the training activities is to lead the employee to broaden his perspective on the work, to situate and to direct his individual actions in the company. This will give him the means to better cope with changes that may affect him and to understand them less, being more versatile. In addition to acquiring technical and organizational knowledge, the worker would benefit from acquiring new skills, especially in the context of wanting to entrust them with increased responsibilities, as supported by new forms of work organization. Problem analysis and problem-solving skills, communication and teamwork, quality control are just some of the skills or experiences that the workforce needs to be productive to be able to adapt to current changes.

The basic tools must be offered to the employee in order to learn and to assimilate the information that will be transmitted to them in order to adapt to a dynamic context. A versatile workforce is able to provide the company with constant adaptation to the changes it is facing. A worker who has learned to learn, who has the opportunity to learn and who uses his new skills is less resistant to change and better adapted to them, because he has more confidence in his ability to tune them. A human resources development plan is essential to bring a certain coherence to the training activities. Sectors, individuals and knowledge need to be targeted in order to be a priority. In terms of succession management, this exercise is essential for the future of the organization. But, again, in order to ensure the efficiency and permanence of skills development, the organization must become an environment that promotes and enhances the acquisition of skills. Training, too often focused on short-term needs, must go far beyond this and aim at long-term development to meet the challenges presented. 
HOLISTICA Vol 11, Issue 2, 2020, pp.140-150

The gap between the skills of new employees and the demands of the service can be important. Employees can complete their skills. Therefore, an equilibrium state must be achieved between what new employees can do and what is required. Although these efforts require a significant investment of time and money, the turnover rate is low and new employees are more productive. As for employees who have been with the company for a long time, they may need training. Qualifications are no longer tailored to their position and help them deliver better job performance.

On the other hand, when the organization decides to train its employees for positions other than those they occupy, it does what is called "human resources development". The difference between training and human resources development is mainly at the level and the objectives of the program. If it involves increasing a person's knowledge or skills to enable him or her to improve performance in the position he or she occupies, it becomes a "training" activity. The content of the program allows the people who follow it to acquire information and/or develop the skills and attitudes necessary to provide good performance in the workplace. Given the dynamism and changing needs of organizations, it is possible to think about staff training. These activities must be integrated into the social and work environment that represents the organization.

Therefore, an assessment of the real needs of the trained people will be answered by adopting the content and training techniques. It is very important for an organization that invests in training: the need for evolution during life, the importance of training actions, as a means of adaptation and growth, potentially available to the company. Preparation is therefore something other than a legal obligation, a social benefit or a means of addressing school inequalities; it is designed, managed, appreciated, as an investment: the company is currently paying an expense from which it will harvest fruits in the future. Without trained labor force, no potential of the country can be fully exploited efficiently and the development process will inevitably be delayed. This means that, without trained labor force, there is no potential for a country, it could not be fully exploited and the development process would inevitably be delayed. It is no longer enough to learn a job once and for all. Such a conception of the profession has harmful consequences for everyone and especially for the company:

- tends to be unfit for change and not equipped for the future;

- which mobilize only partially the abilities of each;

- As for staff, they will suffer from being ill-prepared in the future; the future is in the company or in any other setting.

In the field of training and development, what is at stake is the ability to face the future, better conditions; it is simply the security of the business and the staff. Training also means the communication and development of three fundamental skills:

- the ability to know (general knowledge domain and technology);

- aptitude for know-how (field of practical skills in performing operations); 
- aptitude for knowledge, which mainly concerns evolution of attitude in the work.

Training objectives within the company:

- to satisfy the general evolution of spirits or a fashion;

- increasing profitability;

- to make the staff more suited to their tasks;

- improving the general management of the company;

- the transition from a certain state of mind to a new state of mind;

- Seeks better staff integration by training leaders at all levels towards new command and work attitudes;

- fulfilling the purpose of the company's management policies.

Therefore, the manager must be concerned with climate and organizational management, he will mobilize to avoid or resolve conflicts and to introduce changes at the right time. Improving organizational performance and flexibility requires a participatory solution. The exchange of information and the continuous improvement of skills must lead to participation to ensure long-term success. This participation must be sustainable and give the employees real power. It is not a substitute for trade unionism and must necessarily engage the union. In addition, participation must be based on a permanent communication framework. By participation, a general formula is indicated that refers to all means and experiences designed to engage more employees in the smooth running of the organization, to give them more responsibility for making decisions in their work and to express and influence others' decisions that may affect them. Employee involvement is the ultimate vehicle for employment. It allows employees to make full use of their skills as part of their work, to express themselves about the organization of production and to feel more involved. In addition to the benefits of engagement, employee engagement is a combination of constraints and opportunities within the organization. Participation is a landmark in human resources management, because the knowledgeable and knowledgeable employee will want to use their new knowledge in action and participate. From a profit-sharing perspective, it is clear that an employee who is offered some protection for employment is more likely to cooperate and suggest new ways of doing things.

Beyond the institutionalized forms of participation, there are also forms of informal participation, participation in labor decisions, profit sharing and union involvement. Informal participation is observed in daily work, for example when a supervisor consults his subordinates or allows him to make the final decision. This type of participation, highly appreciated by the employees, is an asset for establishing more formal modes of participation. When it comes to participating in work-related decisions, it can take many forms, such as suggestions programs, a quality circle, and co-management and so on. Employee participation in decision making can be daily (for example, quality control) or an ad-hoc basis (for example, during technological changes). The Committee is of the 
opinion that participation in work-related decisions has a significant impact on employees' performance, as it allows them to exert a direct influence on decisions regarding daily work and working conditions. In addition, participation helps to satisfy an important need for many employees, that of recognition.

Another form of participation is generically known as profit sharing (for example, productivity sharing plans, share ownership plans). Distributing employee profit is essential for engagement. But it is still necessary for the worker to be assured of a certain stability of employment. This workforce stability policy is able to mobilize human resources and ease reluctance to change. Different types of variable compensation, including profit sharing, also help mobilize forces and change behavior in the desired direction to achieve organizational goals. These programs are no longer just for executives; they are an increasingly common tool at all levels of the organization and an effective way to achieve performance goals, as well as to attract and retain the best people. The enthusiasm for variable pay should not, however, hide the need for fair and competitive basic compensation.

\subsection{Attracting and maintaining a skilled workforce}

It is a challenge that causes headaches for business leaders: recruiting and retaining skilled workers. Once this workforce will be developed in an organization, there is still a need to mobilize interest and energy to achieve organizational goals. The problem of attracting and retaining talent is very present and may worsen in the coming years. Employers will make their organization an attractive place to work for job seekers and the workforce instead. The retention of qualified employees, however, far exceeds the financial incentives. This challenge cannot be met without an in-depth understanding of the reality of today's workforce. What is this reality?

- aging workforce;

- intergenerational cohabitation;

- search for work-life balance;

- increasing diversity.

Managers and specialists in human resources management and labor relations are able to understand the needs of allowing the organization to recruit people who possess the skills they are looking for and manage to retain qualified people through appropriate and innovative practices. It is clear that a change in mentalities and behaviors must take place in the workplace. Organizations must be innovative and creative and should not neglect the involvement of stakeholders in ideas and ways of implementing strategies to conserve and adapt the workforce, work experience. Intergenerational living in organizations inevitably has implications for human resources management and labor relations practices, including succession management, mobilization, compensation, recognition, organization and more work and work time organization. 
HOLISTICA Vol 11, Issue 2, 2020, pp.140-150

Globalization reminds us that organizations must be competitive in many cultural contexts at the same time, adapting at the same time to the particularities of their employees from different ethnic and cultural backgrounds. As a result, stereotypes and prejudices can lead to reticence, misunderstanding and even conflicts that affect performance. The challenge is just as important for unions who need to be able to reach these workers, understand their needs, respond to their expectations, and successfully involve them in union life. But we must continue to integrate them into a labor market that respects their skills.

Therefore, professionals in human resources management and labor relations have an indisputable role in implementing the appropriate means for successful integration of people, taking into account their real skills. Approaches must be able to adapt quickly to the diverse transformations and needs of the workforce, being more flexible and open. Organizations recognize their responsibilities for fairness towards people in cultural communities. They develop policies and programs for work equity, complaints management, and education. It is important, however, to create an organizational culture in this direction, engaging people who embrace this culture and highlighting the differences by developing communication skills and an awareness program.

\section{Conclusion}

This presentation highlights the importance of personal development for each of us and it points out the idea that personal development is a process whose welfare, flow or fulfilment states are only natural or emergent natural, but hardly an end in itself, because the process is fine and dynamic. This process increases the maturity, in the sense that the individual develops a more realistic perception of things, of the other to better understand his emotional, cognitive and intellectual functioning. As for the managers, they tend to adopt the personal development approach for them and their employees through training, coaching, psychology, yoga, to ensure relaxation, theatre lessons to cure shyness, etc., which has as a consequence the company's development.

Thus, it can be concluded that the objectives of personal development in management are:

- personal development aims to satisfy the self-fulfilment needs of the employees and to ensure their well-being;

- personal development tends to increase employee productivity;

- personal development enhances employee creation and innovation;

- personal development increases personal skills;

- personal development aims to improve communication in the company, avoid conflicts and create a good working atmosphere;

- personal development allows different people to acquire mental maturity.

\section{Acknowledgement}

This work is supported by project POCU 125040 , entitled "Development of the tertiary university education to support the economic growth - PROGRESSIO", co-financed by the European Social Fund under the Human Capital Operational Program 2014-2020 


\section{References}

Amri, L. (2007). L'importance des pratiques de développement et de formation continue auprès de la main-d'oeuvre vieillissante dans l'administration publique au Québec. https://archipel.uqam.ca/4777/1/M9795.pdf , accessed on Wednesday 23.10.2019, 7.30 pm

Bartlett, K. R. (2001). The relationship between training and organizational commitment: A study in the health care field. Human resource development quarterly, 12(4), 335-352.

Bélanger, P. (2004). Les transformations des logiques de la formation continue en entreprise sur le marché du travail actuel. En ligne: http://www. chaire-competences. uqam. $\mathrm{ca} / \mathrm{pdf} /$ conferences/powerpointconfcomp3mars04.pdf

Bérubé, C. (2000). L'organisation de l'éducation et de la formation des adultes au Québec, In Politiques d'éducation et de formation des adultes, editor Jean-Paul Hautecoeur, Québec/Hambourg, Ministère de l'Éducation et Institut de l'Unesco pour l'éducation

Campeau, A. (2002). Relation âge et travail: recension des écrits, Secrétariat du conseil du trésor Québec. Centre d 'expertise en GRH. Chapelle, Gaetane.

Di Raddo, D. (2002). L'effet de la médiation de la mobilisation des employés dans la relation entre les politiques de ressources humaines et la performance organisationnelle, Mémoire. UQAM, Montréal (Québec)

Dubar, C. (2004). La formation professionnelle continue. La découverte, Collection Repères.

Dubar, C. (2010). La socialisation: construction des identités sociales et professionnelles. Armand Colin.

Garavan, T. N. (1997). Training, development, education and learning: different or the same?. Journal of European industrial training.

Garavan, T., McCarthy, A., Lai, Y., Murphy, K., Sheehan, M., \& Carbery, R. (2020). Training and organisational performance: A meta-analysis of temporal, institutional, and organisational context moderators. Human Resource Management Journal.

Laberge, M., Wils, T., \& Labelle, C. (1995). La formation: un atout en période de forte turbulence. Gestion, Juin.

Lapalme, M. E., Simard, G., \& De la Sablonnière, R. (2002). L'influence des pratiques de gestion des ressources humaines innovatrices sur les différents comportements de mobilisation des directeurs aux services financiers d'une institution bancaire canadienne. Actes du XIIle Congrès de l'AGRH, 317-334.

Miles, M. B., \& Huberman, A. M. (2009). Qualitative data analysis (in Bahasa). UI-Press, Jakarta.

Navarro-Flores, O. (2009). Le partenariat en coopération internationale. Paradoxe ou compromis.

Sassler, S., \& Miller, A. (2017). Cohabitation nation: Gender, class, and the remaking of relationships. Univ of California Press.

Tremblay, M., Guay, P., \& Simard, G. (2000). L'engagement organisationnel et les comportements discrétionnaires: I'influence des pratiques de gestion des ressources humaines. In Internationalisation de la gestion des ressources humaines?.

Tremblay, M. (2001). La mobilisation des personnes : quand la confiance, le cœur, et l'action sont réunis, Les cahiers des leçons inaugurales. HEC

Tremblay, M. (2002). Mobiliser les troupes: un défi stratégique complexe. Effectif, 5(5), 18-25. 